\title{
Harry Brown (c. 1819-1854): Contribution of an Aboriginal guide in Australian exploration
}

\author{
Greg Blyton
}

In recent years there have been a number of important historical works which recognise the important contribution of Aboriginal guides in the exploration of Australia. This article contributes to this field by providing a narrative history of a young Aboriginal man from Newcastle called Harry Brown who accompanied the well-known Prussian explorer, Dr Ludwig Leichhardt, on two expeditions into the interior of Australia in the 1840s. Brown was a highly intelligent, resilient and skilful man who made an enormous contribution to Australian exploration, yet has been overlooked in Australian historiography. His contribution to Australian exploration is an exemplar of Aboriginal influence during the nineteenth century which extends well beyond simplistic portrayals of Aboriginal people as useful, submissive and subservient guides. It will be demonstrated in this article that without the courageous and resolute Brown along with his perspicacity and judgement, the widespread celebration of Leichhardt's discoveries may not have been forthcoming.

The recognition of Aboriginal people in Australian history has made some progress since the late Professor William Stanner chastised Australian historians for failing to acknowledge Aboriginal people in the development of Australia. In 1968, Stanner described this omission as the 'Great Australian Silence' and referred to mentions of Aboriginal people in Australian histories, scant as they were, as a 'melancholy footnote'. ${ }^{1}$ In some ways this may explain why Harry

1 Stanner 1991: 25 
Brown has been overlooked in Australian exploration history. Aboriginal Australian political academics, the late Dr Bruce McGuinness and Dennis Walker, stated in 1985:

\begin{abstract}
Aboriginal heroes, of course, in the main remain nameless ... Blaxland, Lawson and Wentworth ... are depicted as being intrepid explorers who found their way across the Blue Mountains in the greater expanse of Australia. Of course this isn't true. Aboriginal people showed them the way. Without those Aboriginal people they wouldn't have been able to get across those mountains. Those Aboriginal people remain nameless, yet the 'intrepid explorers' are forever glorified by statues and throughout the history books of Australia. There do exist, throughout those historical accounts of what occurred throughout Australian history, many examples of Aboriginal involvement in the blazing of trails, in the establishment of settlements, and in every area of Australian advancement. However, they're hidden within the historical accounts that exist. They remain nameless people. ${ }^{2}$
\end{abstract}

It is evident from nineteenth-century colonial newspapers that Aboriginal guides in Australian exploration were once recognised albeit in a brief, paternalistic and dismissive way. On 2 April 1899, Sydney newspaper the Truth reported that a memorial had been held at the Saint James Church Sydney to remember the tragic death of the European explorer Edmund Kennedy and heroic deeds of '... the faithful aborigine Jackey Jackey on a fateful expedition to Cape York in 1848'. ${ }^{3}$ On 2 November 1889, the Bathurst Free Press and Mining Journal acknowledged the important service provided to Captain Matthew Flinders by 'his black boy, Bungaree', who acted as an intermediary when encountering Aboriginal communities on several sea expeditions, including the circumnavigation voyage around Australia in $1803 .{ }^{4}$ On 30 December 1845, Brown is also given a brief mention in The Australian as 'the black fellow, Harry Brown of Newcastle' who accompanied the European explorer Ludwig Leichhardt. $^{5}$

Nineteenth-century colonial newspapers diminished Aboriginal guides by referring to them in derogatory terms such as 'blacks', 'black boy', 'faithful aborigine'; they were characterised as submissive and obedient servants on European expeditions throughout Australia. Even in the 1970s, popularised historical novels such as Jackey Jackey (1976) by Margaret Paice maintained the portrayal of Aboriginal guides as timid, submissive and feeble-minded. For example, in the following passage from this book Jackey Jackey is depicted as lacking intellectual capacity in a conversation with Dr Vallack:

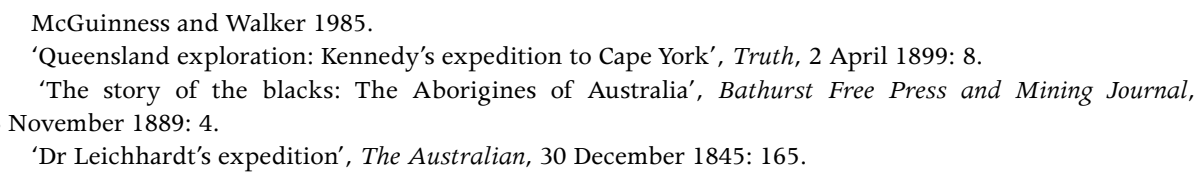


'Where this place, Cape York?' Jackey Jackey ventured timidly, after a moment. 'It's the very top part ...' Dr Vallack scratched his head. 'How do you explain to an Aborigine who had no knowledge of geography outside his own territory?' 'Look,' he said, squatting on his heels and taking up a twig. He began to draw a map in the dust ... Jackey understood only vaguely, but he didn't like to say this. ${ }^{6}$

McGuinness and Walker were justified in their protests, for it was not until the ground-breaking works of historian Henry Reynolds that a more nuanced appreciation of the importance of Aboriginal guides was advanced. Reynolds wrote in With the White People (1990) that the Aboriginal guide has been devalued in Australian exploration history and portrayed as 'ubiquitous, albeit often anonymous' despite playing 'a vital role in the European exploration of the continent' ${ }^{7}$

In recent years, historical research reveals a greater appreciation and insight into the crucial contribution of Aboriginal people to the exploration of Australia in the nineteenth century. The marginalisation of Aboriginal people in Australian exploration history has been noted by Australian historians, such as Nigel Parbury, who wrote, 'In general Aboriginal guides were written out of the legend of Australian exploration and generations of Australian school children learnt of the discoveries and exploits of white explorers. All credit went to the white man' ${ }^{8}$ Similarly, anthropologist Philip Clarke stated in his work Aboriginal Plant Collectors (2008) that Aboriginal guides 'possessed bush skills and a general knowledge of landscapes that could be broadly applied across the continent'. ${ }^{9}$

This represents a major shift in the image of Aboriginal guides as portrayed in 1976 by Paice, who depicted Jackey Jackey as lacking the intellectual capacity to comprehend life beyond his 'territory'. This elision applied also to the subject of this article, Harry Brown. American historian Dane Kennedy in The Last Blank Spaces (2013) notes that 'apart from Leichhardt's passing references' to Brown 'being a member of the Newcastle Tribe ... we know almost nothing' about his life. ${ }^{10}$ Brown is minimally referenced in the Australian Dictionary of Biography as a 'notable Aboriginal from Lake Macquarie who was Leichhardt's guide'. ${ }^{11}$ In the following narrative on the life of this Aboriginal guide, primary sources on Harry Brown, including Leichhardt's journal, will be used along with recent scholarship in the field to show that Brown was among the most effective and skilled Aboriginal guides in nineteenth-century Australian exploration.

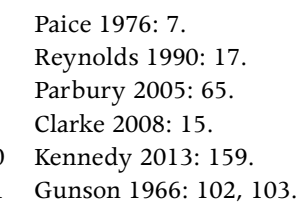




\section{Brown's early years}

One of the major challenges to finding details about the life of an Aboriginal guide overlooked by Australian history is locating the relevant sources. The records left by Aboriginal missionary Reverend Lancelot Threlkeld provide a glimpse into the early years of Brown's life, but little is known of Brown's birthplace, his father, Ngo-ah-ko-ro or Moses (his European ascribed name), or his mother. ${ }^{12}$ According to Threlkeld, Brown was a member of the 'Newcastle Tribe' and was around five years old when the missionary arrived at Newcastle in 1825 to establish a mission for Aboriginal people at Lake Macquarie. It would appear that while Threlkeld was living in Newcastle in a government cottage, Brown and his family lived in close proximity for protection. ${ }^{13}$ Though he does not mention Brown specifically, the missionary provides a picture of his camp's conditions:

The Native camp which surrounded our habitation gave a cheerfulness to the scene at night in consequence of the number of fires kept up by the families at the front of their respective sleeping places, which were mere erections of boughs of trees, or sheets of bark placed upright supported by stakes. The blacks chose our place of residence for their new encampment they having been so frequently molested by many of the prisoners of the crown who perambulated the settlement in the night for purposes that would not bear the light of day. ${ }^{14}$

So, according to Threlkeld, a vexatious relationship existed at Newcastle where these Aboriginal families feared molestation from prisoners. The following year Brown and his family accompanied Threlkeld to establish a mission on the eastern shores of Lake Macquarie. ${ }^{15}$ According to Threlkeld, Brown could already speak 'broken English', as well as being fluent in his traditional Aboriginal language, Awabakal. ${ }^{16}$ As a child, Brown's bilingual skills assisted the missionary record local Aboriginal words and he impressed Threlkeld as intelligent and perceptive:

From childhood Brown exhibited all the smartness of an intellectual youth, equal to any white lad and when teaching him and other aboriginal youngsters to write the English alphabet, at our establishment on the borders of Lake Macquarie, their ingenuity and quickness of apprehension were exhibited, in chopping with their hatchets on the smooth bark of the standing trees in the wilderness, the Roman characters, thus exhibiting their capacity for learning. ${ }^{17}$

12 Gunson 1974, II: 315.

13 Gunson 1974, I: 45, 46.

14 Gunson 1974, I: 45.

15 Gunson 1974, I: 70.

16 Gunson 1974, I: 46 (traditional language known today as Awabakal).

17 Gunson 1974, I: 70. 
In 1828, Threlkeld's relationship with Brown was likely to have been severed when the Aboriginal families at Lake Macquarie returned to Newcastle preferring 'the attractions' of employment in exchange for foods, alcohol and tobacco. ${ }^{18}$ At the time Brown was about eight years old and he returned to Newcastle on the cusp of great social change in the Hunter region. Nevertheless, as we shall see, Brown retained his traditional cultural skills and used them effectively on the two Leichhardt expeditions. It was clearly a major disappointment to Threlkeld who had invested considerable time in educating young Aboriginal boys such as Brown. He reflected his concerns in a letter to the London Missionary Society, stating:

Of eight native children, boys, whom we have attempted to teach the alphabet of their own language, only two remain, but now, about three weeks since the commencement, not one is left; they are all with their friends at Newcastle, where drunkenness is as common with the black boys, 7 or 8 years old. ${ }^{19}$

To what degree Brown was exposed and affected by such 'vices' is difficult to gauge, but when he was around 17 years old he appeared in the Newcastle law court for drunkenness and disorderly conduct. On 6 November 1837, Brown was found guilty of riotous, drunken behaviour and received a five shilling fine or six hours in the stocks. It is not known which punishment he accepted. ${ }^{20}$ Apart from this minor blemish it would seem Brown was a popular young man who had adapted into colonial society. The Maitland Mercury and Hunter River General Advertiser reported on 21 June 1854 that as a youth Brown was 'a favourite among the public at Newcastle' and 'no fishing, boating, shooting or oystering party was complete without him'. ${ }^{21}$

In her ground-breaking work Roving Mariners, Indigenous historian Lynette Russell identifies Aboriginal men and women from Tasmania who played a vital role in the whaling industry in the southern waters of Australia during the nineteenth century. As pointed out by Russell, little is known of the contribution of Aboriginal people in the maritime industry, and although she does not mention Brown it would appear he too was employed in the whaling industry. ${ }^{22}$ According to John F. Mann who accompanied Leichhardt on his second expedition, Brown had made two voyages as a sailor on board a whaler' ${ }^{23}$ Mann's mention of Brown and his whaling experience suggests that

18 Gunson 1974, I: 96.

19 Gunson 1974, II: 227.

20 'Brown (Aboriginal)', (Newcastle Bench Books, AONSW Reel 2722), Free Settler or Felon?, www. jenwilletts.com/searchaction.php?page $=6 \&$ surname $=$ aboriginal\&ship $=\&$ firstname $=$, accessed 21 June 2015.

21 'Newcastle: The last of the Newcastle tribe', The Maitland Mercury and Hunter River General Advertiser,

21 June 1854: 2.

22 Russell 2012.

23 Mann 1888: 8. 
Aboriginal people in the Hunter region may also have been engaged in the maritime industry. ${ }^{24}$ How and when Brown met Ludwig Leichhardt remains a mystery.

At the same time, on the other side of the world, another young man was in European education centres studying natural sciences. According to the Australian Dictionary Biography, Ludwig Freidrich Wilhelm Leichhardt was born in Prussia on 23 October 1813 and was educated at several institutions, including the University of Berlin and the British Museum. ${ }^{25}$ Leichhardt left London in October 1841 aboard the Sir Edward Paget, having completed studies in natural sciences at the British Museum, including botany and geology. ${ }^{26}$ On the voyage to Australia, Leichhardt met James Calvert and John Roper who would become fellow members of the famous expedition from Moreton Bay to Port Essington. Leichhardt arrived in Sydney on 14 February 1842 and ventured to the Hunter region several months later to conduct scientific field trips. Arriving in Newcastle on 20 September with prominent Hunter landowner, Alexander Walker Scott, Leichhardt engaged several Aboriginal guides to assist him during his field studies of fauna, flora and geology in the Hunter Valley, but his diary entries do not reveal Brown as one of them. ${ }^{27}$ According to historian Colin Roderick, Leichhardt had developed a close friendship with Scott, a prominent Hunter Valley pastoralist who may have nominated Brown. ${ }^{28}$ It is highly probable that at the time Leichhardt announced his intention to conduct an expedition into the interior of northern Australia, Brown was a wellreputed and established Aboriginal guide in Newcastle.

Leichhardt's selection of Brown as a member of the expedition indicated that this Aboriginal man from Newcastle had much to offer. Leichhardt's proposal to explore the unknown regions of northern Australia attracted widespread interest, with numerous colonists expressing a desire to take part in the expedition. He wrote, 'in arranging the plan of my journey I had limited the party to six individuals; although many young men volunteered their services, I was obliged to decline their offers' ${ }^{29}$ As a result, Leichhardt had overlooked many of his fellow colonists and rejected notions of European superiority by choosing Brown. At around 22 years, Brown offered the expedition a strong and robust young man, bilingual and possessed of superior hunting, tracking and survival skills. Leichhardt was about to embark on a journey with European

24 Mann 1888: 8.

25 Erdos 1967: 102.

26 Erdos 1967: 102.

27 Darragh and Fensham 2013: 39.

28 Roderick 1988: 237.

29 Leichhardt 1847: xiv. 
colonists with little knowledge of the Australian bush, and as leader of the expedition he had only the limited experience of short excursions into districts surrounding settled parts of the colony. ${ }^{30}$

\section{The first expedition}

A party of six men made up of Leichhardt, Calvert, Roper, John Murphy, William Phillips and Brown left Sydney on 13 August 1844 aboard the steamer Sovereign. ${ }^{31}$ A week later they arrived at Moreton Bay, Brisbane, where preparations for the expedition were finalised. Another four more members were added to the party: John Gilbert, Caleb, Charlie Fisher (an Aboriginal man from Bathurst) and Pemberton Hodgson. ${ }^{32}$ By the end of September the 10 men were ready to commence the expedition with supplies of flour, sugar, tea, guns and ammunition loaded onto carts pulled by 16 bullocks along with 17 horses. On 1 October, the party left Jimbour Station on the Darling Downs and Leichhardt wrote in his journal 'we bid farewell to civilization ... buoyant with hope into the wilderness of Australia'. ${ }^{33}$

To a chorus of 'God Save the Queen' the expedition set off in a north-westerly direction, but before too long buoyant spirits were dampened by the 'refractory bullocks' who 'tore the flour-bags, upset their loads, broke their straps, and severely tried the patience of my companions, who were almost continually occupied with reloading one or other of the restless brutes'.$^{34}$ Few entries are made by Leichhardt about Brown during the first weeks of the expedition, but his Aboriginal compatriot Fisher was mentioned as becoming irritable when Leichhardt delegated him the onerous task of managing the recalcitrant bullocks. Leichhardt wrote on 17 October, 'Charley had been insolent several times, when I sent him out after the cattle, and, this morning, he even threatened to shoot Mr. Gilbert' ${ }^{35}$ So, even in these early stages of the expedition it can be seen that race relations were far from settled with Fisher allegedly being 'impertinent'.

A fortnight later with peace restored, Leichhardt realised their food supplies were insufficient to maintain the expeditionary party. Having anticipated they would be able to supplement provisions with 'game to furnish my party with animal food', Leichhardt wrote, 'I saw clearly that my party, which I had reluctantly increased on my arrival at Moreton Bay, was too large for our

\footnotetext{
30 As noted Leichhardt, Roper and Calvert had only had two years in Australia prior to the expedition.

31 Leichhardt 1847: xiv.

32 Leichhardt 1847: xiv.

33 Leichhardt 1847: xv, xviii, 1.

34 Leichhardt 1847: 12-13.

35 Leichhardt 1847: 14.
} 
provisions. I, therefore, communicated to my companions the absolute necessity of reducing our number' ${ }^{36}$ According to Leichhardt, all members expressed a desire to remain on the expedition, but following a group discussion, Caleb and Hodgson 'who had perhaps suffered most by additional fatigues ... prepared their return for Moreton Bay'. ${ }^{37}$ Again the importance with which Leichhardt viewed Brown and Fisher is emphasised in that he kept the two Aboriginal guides while decreasing the size of the expedition party. Reduced to eight after one month, the party travelled in a north-westerly direction encountering thunderstorms, stifling heat, mosquitoes and sand flies. ${ }^{38}$

As noted by historian Edgar Beale, Aboriginal guides often ascended to become de facto commanders during the course of an expedition. Beale stated of Galmarra, alias Jackey Jackey, 'he soon acquired a reputation for hard work, sagacity and superb bushcrafts ... who emerged as one of its strongest members' ${ }^{39}$ Brown's role during this expedition seems primarily to be as navigator. Occasionally he killed game for food, but spent much of his time scouting ahead of the expeditionary team on horse searching for the best route. ${ }^{40}$ Another one of the crucial roles he performed was locating water. In December 1844, the party were experiencing searing summer heatwaves and fatigue and water supplies were critically low. The situation was dire when Brown made a vital discovery of a 'magnificent lagoon' ${ }^{41}$ On 18 December, Leichhardt noted in his journal, 'The fine lagoons - which I called "Brown's Lagoons" after their discoverer' allowed the party an opportunity to regain their strength and composure. ${ }^{42}$ Abundant vegetation hedging the waterholes provided 'good feed' for the horses and bullocks as well as an opportunity to replenish their water supplies. ${ }^{43}$ It was at 'Brown's Lagoon' the party spent Christmas Day dining on a festive meal of 'suet pudding and stewed cockatoos' ${ }^{44}$

Brown's discovery of a large freshwater lagoon at a time when the party's water supply was low was a critical find, allowing the troupe to regain their stamina, continue their journey and ensure their survival. As pointed out by Kennedy in reference to Brown and Fisher, 'they loom large however, in the expedition journals of Leichhardt and several of his British companions - so large in fact, that they call into question standard assumptions about the role such guides played in relation to the European explorers who were their self-described

\footnotetext{
Leichhardt 1847: 26.

Leichhardt 1847: 27.

Leichhardt 1847: 26, 50.

Beale 1967: 7.

Leichhardt 1847: 52 .

Leichhardt 1847: 76 .

Leichhardt 1847: 79 .

Leichhardt 1847: 79.

Leichhardt 1847: 84
} 
masters' ${ }^{45}$ Brown and Fisher were being utilised to 'herd stock, hunt game, find water', which was vital to the success of the expedition. ${ }^{46}$ Their roles highlight not only the essential importance of Aboriginal guides on such expeditions, but may also explain why some European explorers resorted to abduction.

The essential ability of Aboriginal people to locate water on European exploratory expeditions in Australia has been noted by historian Philip Jones. Jones stated that Aboriginal guides were so vital to European explorers they were often abducted and then coerced to help find water on expeditions into the arid areas of the Australian interior. He wrote that it was commonplace to kidnap Aboriginal people, 'forcing them to reveal water sources' ${ }^{47}$ Historian Mary Anne Jebb corroborates Jones' claim that Aboriginal people were forcibly detained to find water and supply food, noting that the European explorer Frank Hann used Aboriginal people in this way on his expedition to the Kimberley in the 1890s. Jebb stated, 'Thanks to his Aboriginal assistants he had a constant supply of fish, duck, kangaroo and possum as he moved from waterhole to waterhole in the cool season weather' ${ }^{48}$

Indeed this raises questions about the chances of European survival without Aboriginal assistance. How successful would these expeditions have been without Aboriginal guides? Reynolds pointed out that Aboriginal guides not only found water and supplied food, but also saved the lives of lost European explorers. He noted an Aboriginal man, Yuranigh, who found a member of Thomas Mitchell's expedition into the interior of New South Wales in the 1830s. Reynolds stated that when European explorers lost or exhausted their rations they 'probably would have perished' without Aboriginal assistance. ${ }^{49}$ And it is evident that on at least one occasion Brown saved Leichhardt's life when the two became lost in the vicinity of Mount Stewart. On 18 January 1845, Leichhardt left the main party to investigate a navigable route for the expedition accompanied by both Brown and Fisher, highlighting the importance European explorers attached to Aboriginal guides.

After finding water, he sent Fisher back to the main camp to lead them to the newly discovered waterholes - yet again demonstrating how an Aboriginal presence was critical in not only exploring new country, but also retracing past steps. ${ }^{50}$ As noted by Reynolds, Aboriginal guides were also sent back on the tracks to find articles lost or forgotten along the way'. ${ }^{11}$ Leichhardt and Brown

\footnotetext{
Kennedy 2013: 159.

Kennedy 2013: 159.

Jones 2007: 106.

Jebb 2002: 2, 33.

Reynolds 2000: 40, 42.

Leichhardt 1847: 112, 113, 117.

1 Reynolds 2000: 42.
} 
continued exploring new country of 'scrub, plain and forest land' when Brown declared, 'We are lost, we are lost' ${ }^{52}$ It is apparent that Brown believed they were lost and had little faith in Leichhardt's ability to find their way back to the main party. Furthermore, to avert starvation they relied on Indigenous foods procured by Brown's hunting skills, about which Leichhardt stated, 'Oppressed by hunger, I swallowed the bones and feet of the pigeon, to allay the cravings of my stomach'.$^{53}$ It was also Brown who found a way back to the main party. As well as supplying Leichhardt with food, Brown reorientated and saved the European from a perilous situation. Leichhardt stated:

At last, after a ride of about four miles, Brown recognized the place where we had breakfasted on the 19th, when all his gloom and anxiety disappeared at once. I then returned on my south-east course, and arrived at the camp about one o' clock in the afternoon; my long absence having caused the greatest anxiety amongst my companions. ${ }^{54}$

These Aboriginal guides provided a crucial link between the scouting party and the main party as well as being invaluable in instances where the party had to turn back or became lost.

It is likely Leichhardt would have died without Brown providing food and navigating a safe return back to the party. And there are many other instances during this expedition where Brown and Fisher were making the critical decisions that kept the party on track. Reynolds wrote, 'Murphy and Caleb, two members of the Leichhardt's expedition of 1844-45 were missing for two days' and would have perished without Fisher's ability 'to track them' ${ }^{55}$ As Leichhardt stated, there had been 'several other instances of the wonderful quickness and accuracy with which Brown as well as Charley were able to recognize localities which they had previously seen' ${ }^{56}$

Any notions, as found in Australian historiography, that Aboriginal guides were timid, obedient servants on European journeys of discovery are dispelled in the case of Brown and Fisher. Reading Leichhardt's journal, it becomes apparent that neither was timid nor necessarily compliant to the instructions of the European members of the expedition, including Leichhardt. While Brown and Fisher recognised Leichhardt as their leader, neither could be described as servants who unquestionably obeyed their European master. As stated above, the expedition had only been underway a few weeks when Leichhardt's leadership was tested by a recalcitrant Fisher, but this was mild compared to an incident occurring

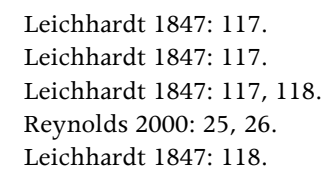


on 15 February 1845. Leichhardt chastised Fisher for leaving the camp without permission and verbally threatened the guide stating, 'I reprimanded him, and told him that I would not allow him any food, should he again be guilty of such conduct'.$^{57}$ Far from being the 'faithful black', Fisher retaliated and launched into a verbal tirade of his own, giving Leichhardt a 'burst' of 'the most violent and abusive language'.$^{58} \mathrm{He}$ writes that Fisher threatened:

to stop my jaw ... Finding it, therefore, necessary to exercise my authority, I approached him to show him out of the camp, when the fellow gave me a violent blow on the face, which severely injured me, displacing two of my lower teeth; upon which my companions interfered, and manifested a determination to support me, in case he should refuse to quit us; which I compelled him to do. ${ }^{59}$

When Fisher was expelled from the party, Brown displayed allegiance to his fellow countryman by refusing a directive from Leichhardt to have no communication with the exiled man. In a test of his authority, Leichhardt informed Brown if he chose to maintain relations with Fisher he too would be ostracised and punished. Leichhardt writes:

When he was going away, Brown told him, in a very consoling manner that he would come by and bye and sleep with him. I was, however, determined that no one within the camp should have any communication with him; and therefore told Brown, that he had either to stop with me entirely, or with Charley. He answered that he could not quarrel with him; that he would sleep with him, but return every morning; and, when I replied that, in such a case, he should never return, he said that he would stop altogether with Charley, and walked off. ${ }^{60}$

Nearly a week passed with Brown and Fisher remaining in proximity, but a distance to the main party. Leichhardt withheld rations from the two Aboriginal men and took away their horses, forcing them to travel on foot. It was a stalemate. Leichhardt had weapons useful for defending against possible attacks from hostile Aboriginal groups, shooting animals and birds for food, and there was safety in numbers. But Brown and Fisher brought skills the party needed. Leichhardt hinted as much when he wrote, 'If I had punished these fellows for their late misconduct, I should have had no occasion for doing so now: but full of their own importance, they interpreted my forbearance, by fancying that I could not proceed without them' ${ }^{61}$ Kennedy highlights the critical reliance on the two Aboriginal men when he writes: 
Given the power relations of racial structure in colonial Australia ... black men who assaulted white bosses could pay for their transgressions with their lives. In this case, however, Leichhardt did little more than expel Fisher from the expedition, figuring that his prospects of survival were slim in such an unfamiliar region where the local population was as likely to be hostile to strange Aborigines as strange Europeans. What Leichhardt failed to anticipate was the decision by Harry Brown to decamp with his black brother ... now the expedition was bereft of a critical source of labour and knowledge of the outback. ${ }^{62}$

As Kennedy points out, power relations were far from clear and there were several incidents where Leichhardt as leader of the expedition was challenged by Fisher and Brown. Yet this insubordination was met with minimal punishment by Leichhardt, highlighting the value he attached to the two Aboriginal men.

The influence of Aboriginal culture on European members of the expedition was also apparent with Brown and Fisher introducing a variety of Indigenous foods into their diets. Leichhardt stated that European members were learning new skills: roasting and eating new foods like pigeons, lizards, ducks and marsupials - critical nutritional sources they had 'formerly ridiculed' ${ }^{63}$ Roasting as a traditional form of Aboriginal cooking and their adoption of an Aboriginal diet therefore proved a vital factor in maintaining the health of the party on such as arduous journey. Leichhardt was open to new ideas and, as Clarke noted, 'a reading of the Leichhardt's journals and surviving correspondence provides ample proof that he was a skilled botanist who possessed a deep interest in how Aboriginal people interacted with the environment ${ }^{\prime}{ }^{64}$ It is also apparent Aboriginal words were being adopted into the colonial vernacular such as 'co-eee'. A confluence of cultural blending was occurring of which historian Michael Davis writes, 'Close scrutiny of these explorer texts conveys a sense that there is another knowledge system at work, barely visible, yet critical in forming a particular type of colonial knowledge - one shaped from the entanglements between European and Aboriginal knowledge' ${ }^{65}$

It is seldom acknowledged in Australian histories that Aboriginal guides such as Brown were exploring their own country albeit far removed from their traditional territory. It raises the question of what motivated Brown to undertake such arduous expeditions. Was it, as historian Frank Walsh has claimed, that 'adventurous young Aborigines penetrated unknown territories with much the same motivation as young Europeans? ${ }^{\prime 66}$ As Clarke noted of Bungaree who

62 Kennedy 2013: 161.

63 Leichhardt 1847: 169.

64 Clarke 2008: 105.

65 Davis 2013.

66 Walsh 2004: 237. 
accompanied Flinders, he had a 'deep interest in exploring', ${ }^{67}$ and there is strong probability Brown was of a similar ilk. In many ways, these expeditions were journeys of discovery for the Aboriginal guides who were experiencing new environments and utilising natural resources in a traditional way. For example, Leichhardt noted on 6 February, 'My black companions loaded themselves with the pretty agates, which they had never seen before, and which they evidently considered to be very valuable; but, after a little time, the weight became inconvenient, and they kept only a few, to strike fire with' ${ }^{68}$ So it can be seen that during the exploratory expedition, Brown was finding new materials to augment his traditional skills in making a fire.

In many ways, Aboriginal guides such as Brown protected European explorers on expeditions in Australia, including against attacks from hostile Aboriginal warriors. In reference to the diaries and journals of European explorers in Australia, Tim Flannery writes, 'careful reading of these accounts reveals that Aborigines were the real, albeit unacknowledged explorers of much of Australia ... they generally carried the guns that fed and defended the expedition, they found the water, and they made the peace' ${ }^{69}$ This was certainly the case when Leichhardt's party were attacked by hostile Aboriginal warriors on the Mitchell River in June $1845 .{ }^{70}$ On 28 June, Leichhardt noted how Brown and Fisher fended off the attack and saved the lives of the group after John Gilbert was speared as he came out of his tent. He wrote, 'Charley and Brown called for caps, which I hastened to find, and, as soon as they were provided, they discharged their guns into the crowd of the natives who instantly fled, leaving Roper and Calvert pierced with spears, and severely beaten by their waddies'.$^{71}$ His account confirms Flannery's argument that Aboriginal guides were protecting European explorers from hostile attacks adding further to their vital importance on expeditions.

Aboriginal guides such as Brown also protected European explorers from the dangers of the bush, including crocodiles. For example, in June 1845, the expeditionary party had reached the tropical northern regions of Australia and were heading into the southern regions of the Gulf of Carpentaria. As they were travelling along the Mitchell River, Leichhardt noted in his journal on 19 June:

Charley and Brown, who had gone to the river, returned at a late hour, when they told us that they had seen the tracks of a large animal on the sands of the river, which they judged to be about the size of a big dog, trailing a long tail like a snake. Charley said that when Brown fired his gun, a deep noise like

67 Clarke 2008: 18.

68 Leichhardt 1847: 140.

69 Flannery 1998: 5.

70 Flannery 1998: 310.

71 Flannery 1998: 309. 
the bellowing of a bull was heard; which frightened both so much that they immediately decamped. This was the first time that we became aware of the existence of the crocodile in the waters of the gulf. ${ }^{72}$

So it can be seen that Brown and Fisher were scouting ahead of the expedition and informing the rest of the party of the potential dangers which lay ahead, safeguarding the party and ensuring their survival. As Clarke notes, 'It is apparent that for Europeans in the Australian bush their safety and the likelihood of success was often placed in the hands of their Aboriginal partners' ${ }^{73}$

Reaching Port Essington on 17 December 1845, the party spent the next month recuperating before boarding the schooner Heroine and returning to Sydney on the 29th where they were greeted by large crowds. Leichhardt stated, 'At Sydney a reception awaited us, the warmth and kindness of which, it is out of my power to describe'. Ten men had left Jimbour Station on the Darling Downs in September 1844, and seven completed the epic walk to the northern extremities of Australia. The following map from Leichhardt's journal shows the path taken by the exploratory party during the expedition: a journey of 3,000 miles involving 14 months of rigorous travel.

Remuneration inequity and the devaluation of Aboriginal people were evident in the variable amounts of money given to members of the expedition. All members received higher sums than the two Aboriginal guides with the exception of Phillips, who received $£ 30$ and also a pardon. Leichhardt received $£ 600$, Calvert and Roper each received £125, Murphy $£ 70$ and Brown and Fisher each received $£ 50$ for their services. Different conditions were also applied to the two Aboriginal members of the expedition whereby their money was 'lodged in the Savings' Bank, and could only be accessed with the approval of the Vice President of that Institution' ${ }^{74}$ 


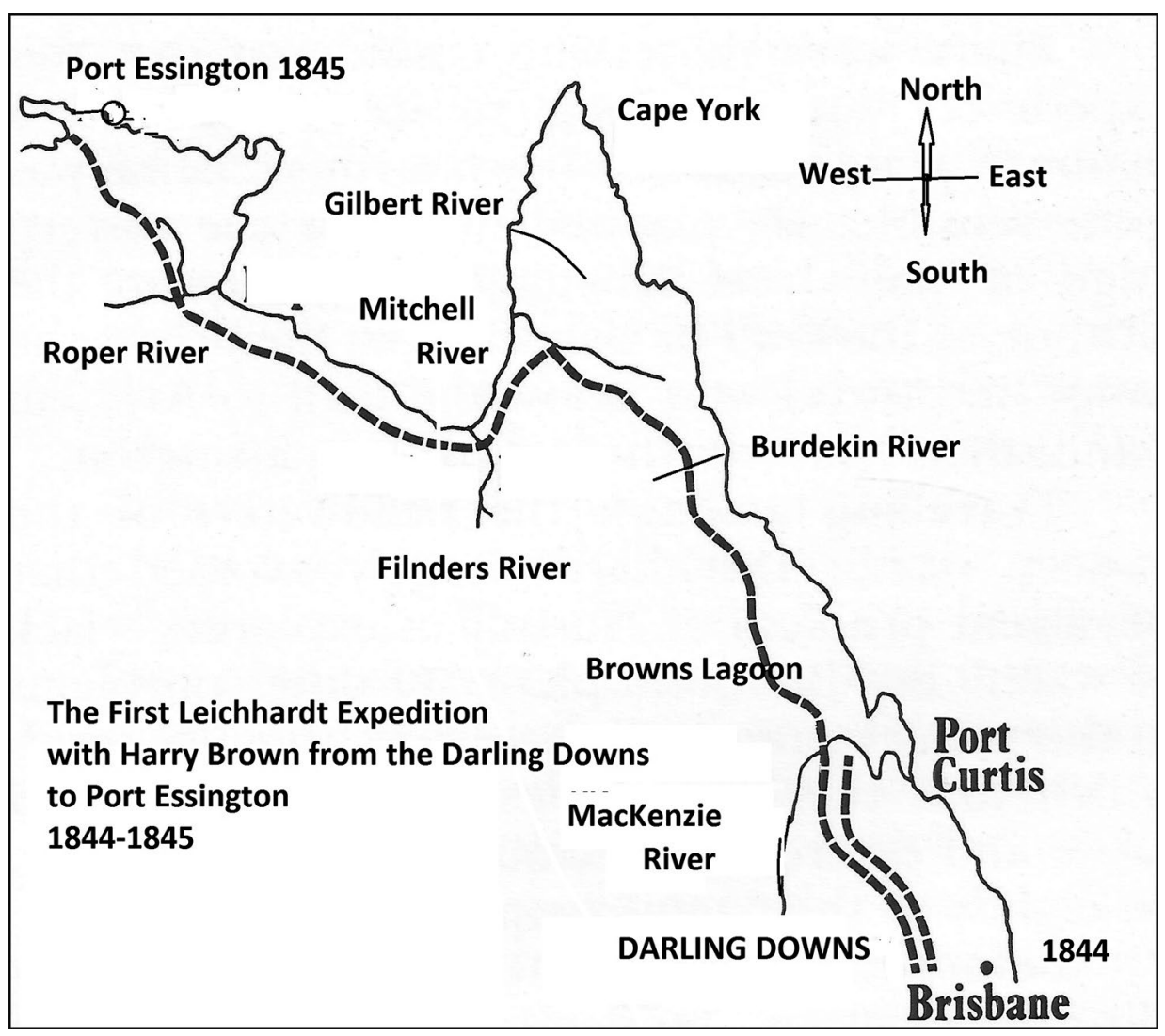

Figure 1: Map showing path taken by Leichhardt's party in 1845. Source: Author.

\section{The second expedition}

Leichhardt conducted a second expedition in 1846 with only Brown remaining from the first expedition party. The new group included John F. Mann, Hovenden Hely, James Perry, Daniel Bunce, Henry Boecking, Henry Turnbull and Wommai, 'a Port Stephens native'. ${ }^{75}$ It was an ambitious plan to cross Australia with half the party having little experience in the Australian bush. Furthermore, the beginning of a hot summer may not have been an ideal starting date as the expedition party of nine men set off on 7 December 1846 from the Darling Downs, trekking along the Condamine River.

75 Mann 1888: 8. 
The following extracts from Mann's diary reveal how dependent the party was on Brown and also wary of decisions made by Leichhardt. Mann wrote, 'I noticed the Doctor was following a wrong course. I did not say anything until Brown road [sic] up to me and verified my supposition. "That Doctor, he go all wrong" he remarked' ${ }^{76}$ Mann informed Leichhardt who defended his decision stating, 'I know where I am going'. ${ }^{77}$ As the party proceeded they came to a difficult ascent of which Mann wrote, 'Brown was at once called to take the lead, and after penetrating this scrub for about ten miles we encamped late in the afternoon on a small open flat'.$^{78}$ Brown's traditional status as an Aboriginal man is evident when he applies his cultural ways and initiates Wommai during the expedition. As Clarke noted, 'Wommai appears to have grown into the role of expedition guide, taking on more responsibility as he gained experience. It was on this first attempt at an east-west crossing that Brown gave Wommai his chest cuts to make him a "young man"'. ${ }^{79}$

During this expedition Brown became very ill with 'ague', a fever characterised by intermittent bouts of fever and chills. Mann noted, 'Brown, who was invaluable in looking after the cattle, was I thought in a dying state' ${ }^{80}$ Brown slowly recovered in the following weeks, but it is evident his leadership was missed during this period of convalescence. Adverse weather, lost cattle and illness added further distress to the expeditionary party culminating in Leichhardt aborting and taking refuge. As noted by historian Renee Erdos, the party was 'delayed by heavy rain and the straying of animals being taken for food and weakened by fever, they were forced, after covering only 500 miles, to return in June $1847^{\prime} .{ }^{81}$

\section{The fatal expedition}

If the second expedition was a failure then Leichhardt's third expedition in 1848 could only be described as disastrous. Without Brown the entire party, which included two Aboriginal guides, Wommai and Billy, set off to cross Australia from east to west and were never seen again. Both these Aboriginal men were from the Port Stephens district. ${ }^{82}$ It is not known why Brown was not part of this third expedition, perhaps due to differences with Leichhardt or it is also possible Wommai had succeeded him. A case can be made that Brown's omission proved

\footnotetext{
Mann 1888: 54.

Mann 1888: 54.

Mann 1888: 54

Clarke 2008: 104.

Mann 1888: 38.

Erdos 1967: 103.

Clarke 2008: 104-105.
} 
the difference between Leichhardt's success and failure. Brown had shown on numerous occasions he was critical to Leichhardt, not only as a navigator, intermediary and hunter, but also as a man capable of defending the expedition against attack. As Leichhardt had noted of his two Aboriginal guides Brown and Fisher, they possessed ability and perception superior to their European counterparts regarding bush survival skills. He wrote, 'The impressions on their retina seem to be naturally more intense than on that of the European; and their recollections are remarkably exact, even to the most minute details ${ }^{\prime}{ }^{83}$

Several search parties were despatched in attempts to discover the fate of Leichhardt and his party, including one led by Hovenden Hely. Hely had participated on the second expedition and requested Brown to assist the investigation. At the time Brown was working as a surveyor's assistant and was so highly regarded by Hely that the colonist engaged him to head the search party. Threlkeld even suggested that if Brown had been on the third expedition Leichhardt may have survived. Reflecting on Brown's omission, he wrote:

One of the name of Brown accompanied the unfortunate Leichhardt in his travels in the interior, and I regret that in the last attempt Brown, the black, was not with the heroic explorer. This aborigine might have proven of the greatest use in extricating the party from local difficulties, or in quickly discovering the ambush of hostile blacks. ${ }^{84}$

The following extract from his epitaph, which was published in the Maitland Mercury and Hunter River General Advertiser, highlights Brown's achievements and demise on 21 June 1854:

'Brown,' the aboriginal who accompanied the lamented Leichhardt in his overland expedition to Port Essington, and who subsequently formed one of Hely's party despatched by Government to endeavour to ascertain the fate of Leichhardt in his attempt to reach Swan River, died at Newcastle on Saturday. About eight weeks ago the deceased, being very much intoxicated, got burnt in the most frightful manner in the Black's camp on the beach. From that time till his death his Sufferings were most intense. ${ }^{85}$

Threlkeld, reflecting on Brown, indicated he had alcohol problems of which the missionary wrote, 'Both are now counted with the dead, Leichhardt in the pursuit of science, Brown following up his evil propensity for strong drink' ${ }^{86}$ Alcohol seems to have had adverse impacts on a number of other prominent

83 Leichhardt 1847: 118.

84 Leichhardt 1847: 118.

85 'Newcastle: The last of the Newcastle tribe', The Maitland Mercury and Hunter River General Advertiser, 21 June 1854: 2.

86 'Newcastle: The last of the Newcastle tribe', The Maitland Mercury and Hunter River General Advertiser, 21 June 1854: 2. 
Aboriginal guides, including Galmarra ${ }^{87}$ and Wylie who was an Aboriginal guide for the explorer Edward Eyre. It would seem that in the post expeditionary period these Aboriginal guides, heroes of frontier exploration in Australia, returned to the camps of their families but succumbed to the effects of alcohol and its adverse consequences.

\section{Conclusion}

This article has examined the important contribution of Harry Brown, an Aboriginal guide from Newcastle, and his critical role in the exploration of Australia in the nineteenth century and challenges perceptions that Aboriginal guides were subservient and insipid servants of European explorers. In a short life of 35 years, Brown spent most of his adult life as an Aboriginal guide, apart from a brief stint in the whaling industry. Brown started his career as a guide by taking colonists from Newcastle on fishing and hunting trips, before becoming a vital member of two major exploratory expeditions. He was enlisted by Hely to lead a search party for Leichhardt on the fateful 1848 expedition, and in his later years was viewed by colonists as a public figure. ${ }^{88}$

Brown was not only an Aboriginal guide, he was an exceptional one. Yet significant details about his life remain undiscovered, such as whether he married or had children, his parentage and burial place. NSW Registry of Births, Deaths and Marriages and local Baptismal records reveal nothing of Brown. Likewise, the life of his fellow countryman Charley Fisher, who has sat proxy to Brown in this narrative, would make interesting historical research. It has been demonstrated in this article that Brown was an Aboriginal guide of the highest quality who was highly regarded by colonial society and who applied his traditional cultural skills and knowledge to provide European members of expeditions with direction, water, food and protection. Brown warrants a meritorious place in the annals of Australian exploration history.

\section{References}

\section{Primary sources}

Gunson, Niel 1974, Australian Reminiscences and Papers of L. E. Threlkeld 1824-1859, 2 vols, Aboriginal Studies Press, Canberra.

87 Gunson 1974, I: 70.

88 'Newcastle: The last of the Newcastle tribe', The Maitland Mercury and Hunter River General Advertiser, 21 June 1854: 2. 
Leichhardt, Ludwig 1847, Journal of an Overland Expedition in Australia, T. \& W. Boone, London.

Mann, John F. 1888, Eight Months with Dr Leichhardt in the years 1846-1847, Turner and Henderson, Sydney.

\section{Newspapers}

The Australian

Bathurst Free Press and Mining Journal

The Maitland Mercury and Hunter River General Advertiser

Truth

\section{Secondary sources}

Beale, Edgar 1967, 'Jackey Jackey (?-1854)', Australian Dictionary of Biography, National Centre of Biography, The Australian National University, adb.anu. edu.au/biography/jackey-jackey-2264, accessed 10 July 2015.

Birman, Wendy 1967, 'Wylie (?-?)', Australian Dictionary of Biography, National Centre of Biography, The Australian National University, adb.anu.edu.au/ biography/wylie-2823, accessed 12 August 2015.

'Brown (Aboriginal)', Newcastle Bench Books, AONSW Reel 2722, Free Settler or Felon?, www.jenwilletts.com/searchaction.php?page $=6 \&$ surname $=$ abori ginal\&ship $=\&$ firstname $=$, accessed 21 June 2015.

Clarke, Philip A. 2008, Aboriginal Plant Collectors: Botanists and Aboriginal People in the Nineteenth Century, Rosenberg Publishing Company, Dural.

Darragh, Thomas A. and Roderick J. Fensham 2013, Leichhardt Diaries: Early Travels in Australia during 1842-1844, Queensland Museum, Brisbane.

Davis, Michael 2013, 'Encountering Aboriginal knowledge: Explorer narratives on north-east Queensland, 1770-1820', Aboriginal History 37, press.anu. edu.au/apps/bookworm/view/Aboriginal+History+-+Volume+thirty+seve n\%2C+2013/10891/davis.xhtml\#toc_marker-6, accessed 21 June 2015.

Erdos, Renee 1967, 'Leichhardt, Friedrich Wilhelm Ludwig (1813-1848)', Australian Dictionary of Biography, National Centre of Biography, The Australian National University, adb.anu.edu.au/biography/leichhardtfriedrich-wilhelm-ludwig-2347, accessed 5 May 2015. 
Flannery, Tim 1998, The Explorers-Stories of Discovery and Adventure from the Australian Frontier, Grove Press, New York.

Gunson, Niel 1966, 'Biraban (?-?)', Australian Dictionary of Biography, National Centre of Biography, The Australian National University, adb.anu.edu.au/ biography/biraban-1781, accessed 2 February 2015.

Jebb, Mary Anne 2002, Blood Sweat and Welfare: A History of White Bosses and Aboriginal Pastoral Workers, University of Western Australia Press, Nedlands.

Jones, Philip 2007, Ochre and Rust Artefacts and Encounters on Australian Frontiers, Wakefield Press, Kent Town, SA.

Kennedy, Dane 2013, The Last Blank Spaces: Exploring Africa and Australia, Presidents and Fellows of Harvard College, Cambridge, MA.

McGuinness, Bruce and Dennis Walker 1985, 'Sharing Histories: Recognising Aboriginal and Torres Strait Islander Pioneers', Indigenous Law Resources, www.austlii.edu.au/cgi-bin/sinodisp/au/other/IndigLRes/car/1993/4/13. html, accessed 10 April 2015.

Paice, Margaret 1976, Jackey Jackey, Australians in History Series for Children, National Library of Australia, Canberra.

Parbury, Nigel 2005, Survival: A History of Aboriginal Life in New South Wales, Ministry of Aboriginal Affairs, Sydney.

Reynolds, Henry 1990, With the White People: The Crucial Role of Aborigines in the Exploration and Development of Australia, Penguin Books, Ringwood, Vic.

2000, Black Pioneers, Penguin, Ringwood, Vic.

Roderick, Colin 1988, Leichhardt the Dauntless Explorer with an Appendix on his last and fatal journey, Angus \& Robertson, Sydney.

Russell, Lynette 2012, Roving Mariners: Australian Aboriginal Whalers and Sealers in the Southern Oceans 1790-1870, State University of New York Press, Albany, NY.

Stanner, William 1991, After the Dreaming, Australian Broadcasting Corporation, Sydney.

Walsh Frank 2004, Great Southern Land: A New History of Australia, Penguin Books Ltd, England. 
This text is taken from Aboriginal History, Volume 39, 2015, edited by Liz Conor, published 2015 by ANU Press,

The Australian National University, Canberra, Australia. 